\section{消費の地理学序説}

\section{関口 武·木崎昭子}

大野義輝 (1961)によれば，わが国にお沙る主 要生活用品の世帯当り購入高には季節変化を示 すものが多く，それは主として気象の影響であ ると論じている。このような問題を取扱う基礎 資料としては総理府統計局消費統計課の手で, 全国主要都市勤労者世带の家計調查の結果をま とめた家計調査年報および月刊の家計調查報告 が刊行されている。約 200 種の商品についての 集計を地理の立場からそれら商品の性犋・季節 変化を検討しその分布をも調べた。方法論的な 疑点なしとしないがその要点を略報したい。

各種商品の消費高について，その季節変化を 検討すると下記のようになる。 I) 季節変 化のないもの II) 季節変化のある女の IIA :ボーナス型( $3 \cdot 6 \cdot 12$ 月にピーク) IIB : ボーナス型以外の季節変化 IIB-夏型 IIB2 一冬型 IIB3一春秋型

米・パンなどの主食には季節変化はない。一 方：電気冷蔵庫・たんす・洋服など高価で耐久 性のある品物はポーナス型になっている。漁期

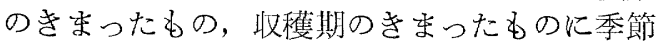
変化のあるのは当然で, これは需要に対する気 候の影響とは言いがたいので除外すると，

夏型——゙ール・ジュース・外用薬・殺虫防

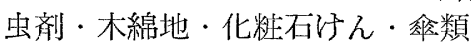

冬型——清酒・化粧クリーム・光熱費
春秋型——絹地・毛糸などが数えられる。こ れらは 1955～62 年の年年の季節変化を検討し て分類した結果である。これは夏型のビールも 最近㤏にも飲玉れるようになり欧米なみに, 季節変化がなくなりつつあるといわれているか らである。しかし，これら商品の消費の季節変 化と気候との関係を説明する機構は明らかでな wo

なお,これ等の統計は全国 28 都市別に集計さ れている。もし，夏型の商品が高温という気候 の影響によるとすれば，その商品の地理的分布 は南方型で, 冬型の商品は北方に消費が多くて しかるべきであろう。このような予想の下に， 上記商品の分布を検討してみた。結果は必ずし も簡単ではなかった。夏型のビール・ジユース・ 化粧石けん・木綿地などは各都市の消費水準の 高低，あるいは地域的特性を示す傾向が強く， 等值線を引くのに困難であった。外用薬・殺虫 剂・唋類については一応地域的特性を示す分布 の等值線は引恬たが，必ずしも南方型ではな く, 他方冬型の商品の消費量も一概に北方型と は言えず，気候の影響を最も顕著に示すはずの 光熱費の分布も複雑であった。何故であろう か。各種商品の単なる消費絶対量・ との季節変 化の検討のみでなく，それぞれの商品に対する 各地方の人人の関心度・嗜好・慣習などの地理 的検討も必要であろう。

大野義輝 (1961)：商業気像 応用気像学大系 2 (工 業気像） $221 \sim 266$
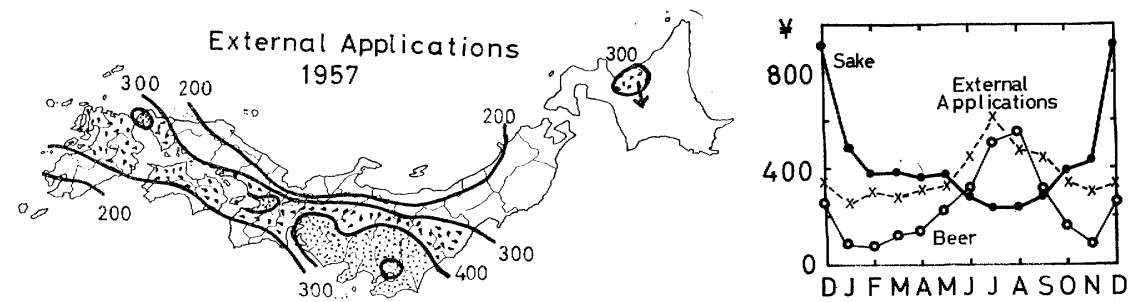

\title{
Geography of Gommodity Consumption in Japan
}

\section{Takeshi SEKIGUTI and Akiko KIZAKI}

Annual and monthly statistics of average family expenditures for principal commodities in 28 cities in Japan various in size have been published regularly by the Bureau of Statistics. Based on these statistics (1955-62), seasonally changing patterns of family expenditures for about 200 commodities have been checked and classified into the following groups:

I) Non-seasonal commodities-staple foods etc.

II) Seasonal commodities A) Bonus-month type - expensive \& durable commodities, such as electric refrigerator, tailored suits, furnitures etc. B) Non-bonus month type Bl-Summer type: beer, external application, insecticide, toilet soap, cotton cloth, umbrella etc. B2-Winter type: sake, toilet cream, fuel \& light B3-Spring \& Autumn type: silk for kimono, wollen yarn.

Distribution maps of annual consumptions of typical summer-type commodities and those of winter-type ones were prepared, but their patterns were not simple and might need detailed geographical analyses. 